\title{
GAMBARAN TITER CRP PADA DEMAM AKUT PASIEN DEMAM BERDARAH DENGUE (DBD) DAN DEMAM TIFOID PADA USIA 3 TAHUN PERIODE JANUARI 2017-JUNI 2018 DI RUMAH SAKIT HERMINA KEMAYORAN
}

\author{
*Sumiati Bedah ${ }^{1)}$, Mahmudah $^{1)}$, Utami Putri $^{1)}$ \\ ${ }^{1}$ Program Studi Analis Kesehatan, Fakultas Kesehatan, Universitas Mohammad Husni Thamrin \\ Correspondence author: Sumiati Bedah, sumiatibedah@yahoo.co.id, Jakarta, Indonesia
}

\begin{abstract}
ABSTRAK
Penyakit infeksi Demam Berdarah Dengue (DBD) dan demam tifoid masih menjadi permasalah kesehatan di Indonesia. Dalam mendiagnosis penyakit infeksi DBD dan infeksi demam tifoid, kedua penyakit infeksi tersebut memiliki gejala-gejala yang hampir sama pada demam hari ke 3 sehingga akan merasa sulit dalam membedakannya. C Reactive Protein merupakan protein fase akut yang dibentuk di hati (oleh sel hepatosit) akibat adanya proses peradangan atau infeksi. Oleh karena itu CRP Kuantitatif sangat baik untuk menilai aktivitas penyakit dalam keadaan demam akut. Penelitian ini bertujuan mengetahui gambaran kadar CRP Kuantitatif pada demam akut karena infeksi DBD dan infeksi demam tifoid di Rumah Sakit Hermina Kemayoran pada usia 3 tahun.

Penelitian ini dilakukan dengan menggunakan data sekunder pada 50 data pasien infeksi DBD dan 50 data pasien infeksi demam tifoid. Alat yang digunakan adalah menggunakan alat Nycocard Reader II dengan metode Sandwich Immunometri. Berdasarkan penelitian yang telah dilakukan prevalensi pasien terinfeksi DBD (34\%), sedangkan prevalensi pasien terinfeksi demam tifoid (80\%).

Hal ini dapat disimpulkan bahwa titer CRP Kuantitatif pada infeksi DBD dan infeksi demam tifoid terdapat perbedaan rata-rata yang bermakna di Rumah Sakit Hermina Kemayoran. Disarankan kepada para klinisi pemeriksaan CRP Kuantitatif agar dapat digunakan sebagai alat bantu penunjang diagnostik pada pasien demam akut.
\end{abstract}

Kata Kunci

: CRP, Dengue, Demam Tifoid

\begin{abstract}
Dengue Dengue Fever (DBD) and typhoid fever are still health problems in Indonesia. In diagnosing DBD infection and typhoid fever infection, both infectious diseases have almost the same symptoms on day 3 fever so it will find it difficult to distinguish them. C Reactive Protein is an acute phase protein formed in the liver (by hepatocytes cells) due to the process of inflammation or infection. Therefore Quantitative CRP is very good for assessing the activity of the disease in a state of acute fever. This study aims to find out the picture of quantitative CRP levels in acute fever due to DBD infection and typhoid fever infection at Hermina Kemayoran Hospital at age 3 years.

The study was conducted using secondary data on 50 DBD infection patient data and 50 data on typhoid fever patients. The tool used is using nycocard reader II tool with Sandwich Immunometry method. Based on studies that have been conducted the prevalence of DBD-infected patients (34\%), while the prevalence of patients infected with typhoid fever $(80 \%)$.

It can be concluded that quantitative CRP titer in DBD infection and typhoid fever infection there is a meaningful average difference in Hermina Kemayoran Hospital. It is recommended to clinicians of quantitative CRP examination to be used as a diagnostic support tool in acute fever patients.
\end{abstract}

Keywords : CRP, Dengue, Typhoid Fever

Open Journal System (OJS): journal.thamrin.ac.id

http://journal.thamrin.ac.id/index.php/anakes/issue/view/34 


\section{PENDAHULUAN}

Penyakit Demam Berdarah Dengue (DBD) yang masih menjadi permasalah kesehatan di Indonesia karena sering menimbulkan Kejadian Luar Biasa (KLB). Perkembangan penyakit ini sangat cepat dan menyebabkan kematian dalam waktu yang singkat. Data pusat media World Health Organization (WHO) menyebutkan bahwa penyebab serius morbiditas dan kematian di kebanyakan daerah tropis dan subtropis di dunia adalah infeksi virus dengue, terutama Asia Tenggara dan Asia Selatan, Amerika Tengah dan Selatan, dan Karibia. Berdasarkan data itu pula, disebutkan bahwa Asia menempati urutan pertama dalam jumlah penderita DBD setiap tahunnya. Sementara itu, WHO juga mencatat bahwa sejak tahun 1968 hingga tahun 2009, Indonesia merupakan negara dengan kasus DBD tertinggi di Asia Tenggara (WHO 2012).

Virus dengue adalah penyebab penyakit infeksi DBD ditularkan melalui vektor nyamuk Aedes aegypti dan Aedes albopictus. Jumlah rataan kasus yang dilaporkan pada $W H O$ setiap tahunnya adalah 0,4-1,3 juta pada 1996-2005. Kejadian Luar Biasa (KLB) terjadi setiap tahun dibeberapa provinsi di Indonesia, yang terbesar terjadi tahun 1998 dan 2004. Laporan pertama kali untuk penemuan penyakit DBD di Indonesia adalah di Kota Jakarta dan Kota Surabaya pada tahun 1968. Kemudian pada tahun 2010 penyakit dengue tersebut telah menyebar di 440 Kabupaten/Kota. Sejak ditemukan pertama kali kasus demam berdarah dengue terus mengalami peningkatan bahkan sejak tahun 2004 terjadi peningkatan kasus. Kenaikan tersebut berbanding terbalik dengan angka kematian atau Case Fatality Rate (CFR) akibat DBD, dimana saat awal penemuannya dilaporkan bahwa CFR sekitar 40\% selanjutnya terus turun diangka $0,87 \%$ pada tahun 2010 .

Angka kasus baru (incidence rate) penyakit DBD per 100.000 penduduk di Indonesia untuk tahun 201065,7 per 100.000 penduduk, tahun 201127,8 per 100.000 penduduk, tahun 201237,1 per 100.000 penduduk, tahun 2013 41,3 per 100.000 penduduk, tahun 2014 39,8 per 100.000 penduduk, dan tahun 2015 49,5 per 100.000 penduduk. Penurunan tajam terjadi pada tahun 2010 ke 2011. Kemudian mengalami peningkatan hingga tahun 2013, tetapi sedikit menurun pada tahun 2014. Selanjutnya kembali meningkat pada tahun 2015. Sedangkan di 2016 sebanyak 202,314 penderita dan 1,593 kematian (Kemenkes RI, 2016).

Demam tifoid (selanjutnya disebut tifoid) merupakan penyakit infeksi akut usus halus yang disebabkan oleh Salmonella typhi penyakit ini mudah menular dan dapat menyerang banyak orang sehingga dapat menimbulkan wabah (Filio, et al., 2013). Laporan menurut Centers for Disease Control (CDC) di negara maju diperkirakan 5.700 kasus terjadi setiap tahunnya, demam tifoid masih umum di negara berkembang dimana hal itu memengaruhi sekitar 21.5 juta orang per tahun (CDC, 2013). Secara global diperkirakan setiap tahunnya terjadi sekitar 21 juta kasus dan 222.000 menyebabkan kematian. Demam tifoid menjadi penyebab utama terjadinya mortalitas dan morbiditas di negara-negara berpenghasilan rendah dan menengah (WHO, 2016). 
Komplikasi serius dapat terjadi hingga 10\%, khususnya pada individu yang menderita tifoid lebih dari 2 minggu dan tidak mendapat pengobatan yang adekuat. Case Fatality Rate (CFR) diperkirakan 1-4\% dengan rasio 10 kali lebih tinggi pada anak usia lebih tua (4\%) dibandingkan anak usia $\leq 4$ tahun $(0,4 \%)$. Pada kasus yang tidak mendapatkan pengobatan, CFR dapat meningkat hingga 20\%. Tanpa pengobatan yang efektif, demam tifoid memiliki Case Fatality Rate (CFR) sebesar 10-30\%. Namun jumlah itu berkurang menjadi 1-4\% setelah menerima pengobatan yang adekuat (Crump, 2010).

Penyakit demam tifoid tersebar di seluruh wilayah dengan kejadian yang tidak berbeda jauh diantar daerah (Widoyono, 2011). Sebuah penelitian yang dilakukan didaerah kumuh dikawasan Jakarta memperkirakan angka kejadian demam tifoid 148,7 per 100.000 penduduk per tahun pada kelompok usia 2-4 tahun, 180,3 per 100.000 penduduk pada kelompok usia 5-15 tahun dan 51,2 per 100.000 penduduk diantaranya lebih dari 16 tahun, dengan diawali usia rata-rata 10,2 tahun (Ochiai, 2008) Ada beberapa penyakit yang apabila diamati secara klinis akan sulit membedakan diagnosisnya. Dan apabila salah dalam mendiagnosis penyakit yang diderita maka akan menyebabkan fatal pada pasien. Contohnya dalam mendiagnosis penyakit demam tifoid dan Demam Berdarah Dengue (DBD), karena penyakit tersebut memiliki gejala-gejala yang hampir sama sehingga akan merasa sulit dalam membedakannya. Bahkan dalam praktek sehari-hari dokter terlalu sering memberikan antibiotik untuk pasien tersebut walaupun kita belum pasti tahu penyebabnya. Dari penelitian-penelitian ditemukan paling banyak penyebab demam yang tidak diketahui adalah infeksi bakteri (Judarwanto, 2009).

Pada suatu infeksi, terjadi proses inflamasi yang menghasilkan sitokin yang merupakan stimulator inti dari produksi protein fase akut, termasuk protein $\mathrm{C}$-reaktif $(C$-reactive protein $=C R P)$. Pada respons inflamasi akut, kenaikan konsentrasi komponen akan berbeda-beda sesuai dengan penyebabnya. Dengan demikian, pasien demam dapat memiliki kadar CRP yang berbeda pula. Variasi ini menunjukkan bahwa produksi protein fase akut tergantung pada perbedaan sitokin spesifik dan patofisiologi penyebab yang mendasari. Oleh karena itu, CRP mungkin dapat digunakan sebagai alat bantu diagnostik pada demam akut yang terjangkau, cepat dan murah (Charlan 2008).

Pada penelitian Idhayu tahun 2014 mendapatkan hasil sebaran CRP tidak normal. Didapatkan bahwa nilai rata-rata CRP pada infeksi demam dengue lebih kecil dibandingkan rata-rata CRP pada demam tifoid. Sementara itu, pada hasil uji beda rata-rata CRP antara infeksi demam dengue dengan demam tifoid, diketahui bahwa berdasarkan derajat berat infeksi, didapatkan rata-rata CRP 11,65 mg/L (1 $\mathrm{mg} / \mathrm{L}-46 \mathrm{mg} / \mathrm{L}$ ) untuk demam dengue dan $53 \mathrm{mg} / \mathrm{L}(8 \mathrm{mg} / \mathrm{L}-150 \mathrm{mg} / \mathrm{L})$ untuk demam tifoid.

Pemeriksaan CRP juga dapat digunakan untuk menentukan peradangan yang ditimbulkan karena adanya infeksi virus seperti penyakit DBD maupun karena infeksi bakteri seperti tifoid. Hal ini berguna untuk membantu menentukan perkembangan penyakit serta melihat efektivitas pengobatan/terapi yang telah diberikan oleh klinisi.

Maka peneliti ingin melakukan penelitian berdasarkan identifikasi masalah tersebut, hanya dibatasi pada perbandingan hasil CRP pada penyakit DBD dan demam tifoid. Selain itu, penelitian ini juga 
bertujuan untuk mengetahui nilai rata-rata kadar CRP dalam membedakan diagnosis infeksi dengue dan demam tifoid. Dengan demikian, diharapkan dapat dilakukan penegakkan diagnosis yang cepat dan tepat pada hari-hari awal demam sehingga membantu menghemat penggunaan antibiotik.

\section{METODOLOGI PENELITIAN}

Waktu penelitian dilaksanakan mulai bulan Mei 2018 sampai dengan Agustus 2018. Data penelitian ini diperoleh dari Rekam medis satu tahun terakhir (bulan Januari 2017 - Juni 2018). Tempat pengambilan data di Rs. Hermina Kemayoran. Populasi adalah semua data pasien yang melakukan pemeriksaan positif demam DBD dan demam tifoid di Rs. Hermina Kemayoran bulan Januari 2017 Juni 2018. Sampel adalah data hasil pemeriksaan CRP pada sampel positif demam DBD 50 pasien dan positif demam tifoid 50 pasien yang melakukan pemeriksaan CRP, di RS Hermina Kemayoran, pada periode bulan Januari 2017-Juni 2018. Dalam penelitian ini adalah data sekunder. Langkahlangkah pengumpulan data yang dilakukan adalah sebagai berikut : Mengajukan permohonan surat ijin pengambilan data ke Institusi pendidikan Universitas $\mathrm{MH}$. Thamrin. Surat ijin pengambilan data ditujukan kepada Direktur dan Rekam medis Rs. Hermina Kemayoran. Data yang digunakan adalah data yang berasal dari Rekam medis dari Rs. Hermina Kemayoran. Selanjutnya data yang diperoleh dihitung dan dianalisis. Data yang diperoleh dalam penelitian ini kemudian dilakukan perhitungan presentase. Adapun rumus perhitungannya adalah sebagai berikut :

$\%=\frac{x}{n} * 100$

Keterangan :

$\%=$ presentase hasil CRP

$\mathrm{x}=$ Jumlah sampel pasien DBD atau demam tifoid

$\mathrm{n}=$ jumlah seluruh sampel yang diperiksa pasien DBD atau demam tifoid.

Hasil disimpulkan dan disajikan secara deskriptif.

\section{HASIL DAN PEMBAHASAN}

\section{Hasil}

Menurut data yang didapat untuk penelitian titer CRP pada demam akut pasien terdiagnosa DBD dan demam tifoid di Laboratorium Hermina Kemayoran pada bulan Januari 2017-Juni 2018 masingmasing 50 data pasien DBD dan 50 data pasien demam tifoid. Data yang diperoleh selengkapnya dapat dlihat pada tabel berikut ini. 
Tabel 1.

Hasil Pemeriksaan Titer CRP Pada Pasien DBD Dan Demam Tifoid Bulan Januari 2017-Juni 2018 Di Rs. Hermina Kemayoran

\begin{tabular}{ccccc}
\hline \multirow{2}{*}{ Penyakit } & \multirow{2}{*}{$\begin{array}{c}\text { Jumlah } \\
\text { Sampel }\end{array}$} & Terendah & Tertinggi & Rata-rata \\
\cline { 3 - 5 } DBD & 50 & 5 & 21 & 7,16 \\
\hline \multirow{2}{*}{ TIFOID } & 50 & 5 & 120 & 41,98 \\
\hline
\end{tabular}

Pada tabel 1, didapatkan pada pasien DBD titer terendah $5 \mathrm{mg} / \mathrm{L}$, titer tertinggi $21 \mathrm{mg} / \mathrm{L}$. Pada pasien demam tifoid didapatkan titer terendah $5 \mathrm{mg} / \mathrm{L}$, titer tertinggi $120 \mathrm{mg} / \mathrm{L}$. Sedangkan rata-rata hasil titer CRP pada pasien demam DBD adalah 7,16 mg/L dan pada penderita demam tifoid 41,98 mg/L.

Tabel 2

Distribusi Frekuensi Titer CRP pada Pasien DBD dan demam tifoid

Periode Januari 2017-Juni 2018 Di Rs. Hermina Kemayoran

\begin{tabular}{ccccc}
\hline \multicolumn{1}{c}{ KADAR CRP } & DBD & $\%$ & TIFOID & $\%$ \\
\hline NORMAL $(<6$ mg/L) & 33 & 66 & 10 & 20 \\
\hline DI ATAS NORMAL & & & & \\
$(\geq 6$ mg/L) & 17 & 34 & 40 & 80 \\
\hline \multicolumn{1}{c}{ TOTAL } & $\mathbf{5 0}$ & $\mathbf{1 0 0}$ & $\mathbf{5 0}$ & $\mathbf{1 0 0}$ \\
\hline
\end{tabular}

Data tabel 2, dari hasil CRP normal pasien DBD pada usia 3 tahun didapatkan distribusi frekuensi 66\% sebanyak 33 pasien, dan hasil CRP diatas normal didapatkan distribusi frekuensi 34\% sebanyak 17 pasien. Hasil CRP normal pasien demam tifoid pada usia 3 tahun didapatkan distribusi frequensi $20 \%$ sebanyak 10 pasien, dan hasil CRP diatas normal didapatkan distribusi frequensi $80 \%$ sebanyak 40 pasien.

\section{Pembahasan}

Dari penelitian yang dilakukan terhadap masing-masing data 50 hasil pemeriksaan titer CRP pada penderita DBD dan tifoid. Berdasarkan tabel 1, terlihat DBD yang disebabkan oleh infeksi virus dengue mempunyai rata-rata titer CRP yang lebih rendah 7,16 mg/L dibandingkan pasien dengan infeksi bakteri Salmonella typhi $41,98 \mathrm{mg} / \mathrm{L}$. Terdapat perbedaan rata-rata yang bermakna antara infeksi dengue dan demam tifoid. Hal ini sesuai dengan penelitian yang telah dilakukan sebelumnya oleh Idhayu tahun 2014 yang menemukan bahwa rata-rata dari 102 pasien infeksi dengue 11,65 mg/L dan pada 86 pasien infeksi demam tifoid adalah $53 \mathrm{mg} / \mathrm{L}$. Perbanding lurus dengan tinjauan teori menurut Netea MG 2010 dapat dilihat dari sitokin proinflamasi yang berperan pada kedua infeksi tersebut peningkatan CRP pada infeksi bakteri lebih tinggi dari infeksi virus. 
Pada penelitian ini, CRP diperiksa pada hari ketiga saat timbul stimulus, sintesis CRP di hati dimulai dengan sangat cepat dan kadar CRP mencapai puncaknya sekitar 48 jam, dengan waktu paruh CRP adalah sekitar 19 jam dan setelah itu, nilai CRP akan relative konstan atau bersifat tetap. Pasien pada kelompok infeksi dengue dan demam tifoid saat pertama kali masuk rumah sakit didapatkan suhu tubuh $\geq 38^{\circ} \mathrm{C}$ selama 3 hari.

Berdasarkan tabel 2, prevalensi pasien terinfeksi DBD terbanyak didapatkan dengan usia 3 tahun (34\%) sebanyak 17 pasien, sedangkan prevalensi pasien terinfeksi demam tifoid dengan usia 3 tahun sebayak 40 pasien (80\%). Berdasarkan penelitian Salsabila tahun 2017, menemukan bahwa anak usia $<12$ tahun lebih sensitif terhadap infeksi virus dengue dan belum mampu melakukan tindakan preventif, dimana didapatkan data sebanyak 108 anak usia $<12$ tahun terserang infeksi dengue, dan sebanyak 28 anak usia $\geq 12$ tahun terserang infeksi dengue.

Respon imun tubuh pada pasien DBD sel monosit, limfosit-B, dan sel mast yang terinfeksi virus dengue akan menghasilkan berbagai sitokin yang berbeda. Menurut Neta tahun 2010, pada tiga hari pertama demam dengue, konsentrasi serum Tumor Necrosis Factor- $\alpha$ (TNF- $\alpha$ ), interleukin (IL) -2, IL6 , dan interferon (IFN)-c adalah yang tertinggi, sedangkan IL-10, IL-5, dan IL-4 cenderung muncul kemudian. Produksi sitokin proinflamasi IL-1, TNF- $\alpha$ dan terutama IL-6 dari berbagai sel tersebut menstimulasi sintesis CRP oleh liver.

Prevalensi demam tifoid paling tinggi pada usia 3-19 tahun karena pada usia tersebut orang-orang cenderung memiliki aktivitas fisik yang banyak, dan kurang memperhatikan pola makannya, akibatnya mereka cenderung lebih memilih makan di luar rumah, atau pengasuh anak yang mempunyai pendidikan rendah tentang kebersihan. Faktor yang mempengaruhi kejadian demam tifoid antara lain usia, kebiasaan jajan, kebiasaan cuci tangan, pendidikan, dan sumber air. Hasil penelitian ini menunjukkan bahwa terdapat hubungan yang bermakna antara usia dengan kejadian demam tifoid. Hal tersebut sesuai teori yang menyatakan bahwa usia 3-19 tahun memiliki risiko besar mengalami demam tifoid. Hasil penelitian ini juga sama dengan penelitian sebelumnya yang menunjukan bahwa usia merupakan faktor yang signifikan terhadap kejadian demam tifoid pada anak (Rustam MZ. 2010).

Pada demam tifoid, tubuh membentuk respon imun natural dimulai dengan pengenalan komponen bakteri Salmonella thypi seperti lipopolisakarida (LPS) dan Deoxyribonucleic acid (DNA), sel fagosit melakukan pengambilan dan penghancuran bakteri. Peran ini dilakukan oleh makrofag, sel NK, dan neutrophil. Adapun pengeluaran mediator inflamasi berfungsi untuk memperkuat repon imun. Makrofag mensekresi IL-1, IL-6, IL-8,IL-12, IL-15, IL-18 dan TNF bekerja sinergis untuk meningkatkan aktivasi sel $\mathrm{T}$ dan respon inflamasi akut (Ali YF, 2010).

Lipopolisakarida dari Salmonella akan mengaktivasi interleukin, TNF dan interferon, serta akan mengaktivasi Toll-Like Receptor 4 (TLR 4), dimana TLR 4 ini berfungsi mengaktifkan NF-kB, yang selanjutnya akan menginduksi sinyal transduksi dan sitokin proinflamasi dari dalam sel, yang akhirnya meningkatkan CRP (Hue NT, 2009). 
Penyakit infeksi DBD yang disebabkan oleh virus, dan infeksi tifoid disebabkan oleh bakteri, namun keduanya mempunyai kemiripan gejala klinis, sehingga menimbulkan kesulitan dalam melakukan diagnosis secara cepat namun adekuat. Kedua penyakit tersebut bersifat akut sehingga dapat menimbulkan respon tubuh berupa pembentukan protein fase akut antara lain CRP.

\section{SIMPULAN}

Berdasarkan data yang didapatkan dari 50 pasien DBD dan 50 pasien demam tifoid di Rs. Hermina Kemayoran pada anak usia 3 tahun periode Januari 2017-Juni 2018 dapat disimpulkan bahwa : DBD yang disebabkan oleh infeksi virus dengue mempunyai rata-rata titer CRP yang lebih rendah 7,16 $\mathrm{mg} / \mathrm{L}$ dibandingkan pasien demam tifoid dengan infeksi bakteri Salmonella typhi 41,98 mg/L. Terdapat perbedaan rata-rata yang bermakna antara infeksi dengue dan demam tifoid. Gambaran hasil titer CRP pasien terinfeksi DBD sebanyak 17 pasien (34\%). Gambaran hasil titer CRP pasien terinfeksi demam tifoid sebanyak 40 pasien (80\%).

\section{UCAPAN TERIMA KASIH}

Penulis mengucapkan terima kasih Kepala Laboratorium Rs. Hermina Kemayoran dan Prodi D III Analis Kesehatan Fakultas Kesehatan Universitas MH Thamrin. dalam penelitian ini.

\section{DAFTAR PUSTAKA}

1. Abimbola, I.O. 2013. Knowledge and Practice In The Use of Antibiotics Among A group of Nigerian University Students. International Journal of Infection Control. 9(7): Hal. 1-8.

2. Ali YF, Abdulaziz AM. 2010. Circulating interleukin-6 and tumor necrosis factor receptor-1 predict resistance to therapy of typhoidal salmonellosis, Egypt J Pediatri Allergy Immunol ; 8(2):55-9.

3. Butler, T.. 2011. Treatment of Typhoid Fever in the 21 st Century: Promises and Shortcomings, Clinical Microbiology and Infection, pp. 959-963.

4. Carlan P. 2008. Rp vs ESR Assessing \& measuring the inflammatory response. Diunduh dari http://www.bpac. org.nz.

5. Centers for Disease Control and Prevention. 2013. Typhoid Fever. National Center for Emerging and Zoonotic Infectious Diseases

6. Crump, J.A. dan Mintz, E.D. 2010. Global Trends in Typhoid and Paratyphoid Fever. Clin Infect Dis, 50(2): 241-246

7. Dalal, S., and Zhukovsky D.S., 2010. Pathophysiologi and Management of Fever, J. Support Oncology

8. Filio, M., Gregory, T., Marianna, K. \& George , A., 2013. mary mallon (1869 - 1938). the history of typhoid fever and annals of gastroenterology, Volume 26, pp. 1 - 3.

9. Garna, Herry. 2012 .Buku Ajar Divisi Infeksi Dan Penyakit Tropis. Jakarta: Salemba medika

10. Hue NT, Lanh MN, Phuong LT, Vinh H, Chinh NT, Hien TT, et al. 2009. Toll-Like Receptor 4 (TLR4) and Typhoid fever in vietnam. Plos one;4(3):e4800. Epub March 11. 
11. Idhayu,A.T, 2014. Jurnal Perbedaan Kadar C-Reactive Protein pada Demam Akut karena Infeksi Dengue dan Demam Tifoid . Jakarta. Fakultas Kedokteran Universitas Indonesia/RS dr. Cipto Mangunkusumo.

12. Judarwanto, W. 2009. Demam Yang Dapat Mengancam Jiwa. Diambil kembali dari infodemam.com: https://infodemam.com/2009/02/19/demam-yang-dapat-mengancam-jiwa/

13. Kaneshiro, N.K., and Zieve, D. 2010. Fever. University of Washington. Available from:http://www.nlm.nih.gov/medlineplus/ency/article/000980.htm. [Updated 29 Juli 2018]

14. Kawthalkar SM. 2010. Essentials of Clinical Pathology. Jaypee Brothers Medical Publisher Ltd; 218-219

15. Kemenkes RI. 2016. Infodatin (Situasi Demam Berdarah Dengue di Indonesia). Jakarta:Pengolahan Data dan Informasi, Kementerian Kesehatan Republik Indonesia.Tersedia di:http://www.depkes.go.id/download.php?file=download/pusdatin/infodatin/InfoDatin2016TB.pdf.

16. Kementerian Kesehatan RI. 2010. Pusat Data dan Surveilans Epidemiologi. Buletin Jendela Epidemiologi Topik Utama Demam Berdarah Dengue. Vol. 10. H.1, 6, 9, 21-24. Jakarta.

17. Kementrian Kesehatan RI. 2011. Penatalaksanaan Demam Berdarah Dengue di Indonesia. Ditjen PPM \& PPL. Jakarta.

18. Keputusan Menteri Kesehatan Nomor 365/MENKES /SK/V/2006 tentang Pedoman Pengendalian Demam Tifoid.

19. Kunoli, Firdaus J., 2013. Pengantar Epidemiologi Penyakit Menular Untuk Mahasiswa Kesehatan Masyarakat. Jakarta: Trans Info Media.

20. Nani. 2014. http://elibrarystikesnn.ac.id/files/disk1/3/e-library\% 20stikes\%20hasanudin-saribungap_108-/articel-8.pdf.

21. Nasronudin, dkk . 2011. Penyakit Infeksi di Indonesia Solusi Kini dan Mendatang-Surabaya; Pusat Penerbitan dan Percetakan Unair.

22. Nelwan. 2012. Tatalaksana Terkini Demam Tifoid. CKD 192. Vol. 39. NO 4.

23. Netea MG, Kullberg BJ, Van der Meer JW. 2010 Circulating cytokines as mediators of fever. Clinical infectious disease : an official publication of the Infectious Disease Society of America no 31 Suppl 5:S178-84. Epub 2010/12/13

24. Newton, A. E., dan Mintz, E., 2013, Typhoid and Paratyphid Fever, http://wwwnc.cdc.gov/travel/yellowbook/2018/chapter-3-infectious-diseases-related-totravel/typhoid-and-paratyphoid-fever. (Diakses pada tanggal 20 Februari 2018) al, Mers-CoV: Zoonosis Baru, Farmancia, Vol. XIII No. 11, pp. 24-29

25. Ochiai, R.L., 2008. Acosta, C.J., Danovaro, H.M.C., Baiqing, D., Bhattacharya, S.K., dan Agtini, M.D.. A Study of typhoid fever in five Asian Countries: Disease burden and Implications for controls. Bulletin of the World Health Organization, 86(4): 260-268

26. Pratama, Gede, K., Wiradewi,Lestari. 2015. Efektifitas Tubex Sebagai Metode Diagnosis Demam Tifoid. ISM.Vol 2. No 2089 -9084. Hal 71. Bali: Universidas Udayana.

27. Profil Klinik Infeksi Virus Dengue pada... Available from: https://www.researchgate.net/publication/312199310_Profil_Klinik_Infeksi_Virus_Dengue_pad a_Bayi_di_Surabaya [accessed Aug 15 2018].

28. Purwadianto, A., Malik, M.D., Syukur, A., Taher, A., Soebandrio, A., Hardjosastro D., et al, 2014, Mers-CoV: Zoonosis Baru, Farmancia, Vol. XIII No. 11, pp. 24-29

29. Ripani Musyaffala, 2010, widal-dan-typhoid-fever,file://localhost/D:/.html,

30. Rudholph, Abraham M, Julien I.E Hoffman, Colin D. Rudolph. 2014. Buku ajar pediatric Rudolph volume 1. Jakarta: EGC

31. Rustam MZ. 2010. Hubungan Karakteristik Penderitaan dengan Kejadian Demam Tifoid pada Pasien Rawat Inap di RSUD Salewangan Maros. Skripsi. Universitas Airlangga, Surabaya.

32. Salsabila, O., Shodiqin,M.A.,Rachmawati, D.A. 2017. Analisis Faktor Risiko Terjadinya Sindrom Syok Dengue pada Anak di RSUD dr. Soebandi Kabupaten Jember. Skripsi. Fakultas Kedokteran, Universitas Jember.

33. Soedarmo SS, Garna H, Hadinegoro SR, Satari HI, 2008. penyunting. Buku ajar infeksi dan pediatri tropis. Edisi kedua. Jakarta: Ikatan Dokter Anak Indonesia;.h.47-55. 